ACTA MYCOLOGICA

Vol. 48 (2): 257-262

2013
Dedicated to Professor Maria Ławrynowicz on the occasion of the 45th anniversary of her scientific activity

DOI: $10.5586 / \mathrm{am} .2013 .027$

\title{
Valsa viburni, a rare fungus in Europe?
}

\author{
VERA HAYOVA \\ Department of Mycology, M.G. Kholodny Institute of Botany \\ Tereschenkivska 2, UA-01601 Kiev, vera.hayova@i.ua
}

Hayova V.: Valsa viburni, a rare fungus in Europe? Acta Mycol. 48 (2): 257-262, 2013.

The paper provides brief illustrated description and general distribution of Valsa viburni. The fungus is found to be highly host-specific and confined to Viburnum lantana. According to currently available data on its distribution, the species has small number of records, fragmented range and is shown to be rare in Europe. However, before assessment of the species, information on any additional unrecorded specimens is needed. On the example of V viburni, some issues on fungal conservation for species of microfungi are considered.

Key words: Valsa viburni, rare fungus, Viburnum lantana, conservation of microfungi

\section{INTRODUCTION}

The genus Valsa Fr. 1849 (Valsaceae, Diaporthales) comprises mostly corticolous fungi inhabiting various woody plants worldwide, often found in their Cytospora anamorphic states (Spielman 1985; Castlebury et al. 2002; Rossman et al. 2007). Majority of Valsa species have a wide host range and are associated with members of one or several plant families. Some are known to occur on particular host genus, for example, on Eucalyptus (Adams et al. 2005). Valsa viburni Fuckel 1870 is apparently a strictly host-specific fungus confined to a single host species, Viburnum lantana (Adoxaceae).

Distribution of this fungus is likely much narrower than its host range. $V$. lantana, or wayfaring tree, is native to Europe, northern Africa, Asia Minor, Caucasus and northwestern Iran. The plant is also cultivated outside its native range. For example, it is introduced in North America where it has naturalized and reported invasive in some parts of USA (http://plants.usda.gov/). However, all but one of known up to now reports of Valsa viburni are restricted to Europe, except one record from Africa, Morocco. Moreover, the species is mostly known by a single record in each country, except duplicates in original and exsiccate collections dated back to the 19th century and six recent records from four localitites in Ukraine. 
Thus the fungus appears to be rare. More information on its distinctive characters and current distribution is provided below. One of the main purposes of the paper is to draw attention of mycologists studying corticolous microfungi to this species which seems well defined and quite easily distinguished. The paper is also aimed to contribute to fungal conservation issues, particularly conservation of microfungi, using a single host-specific species as an example.

\section{MATERIALS AND METHODS}

Morphological description of anamorphic and teleomorphic states of $V$ viburni is mostly based on the specimens collected by author in 1983-1984 and 2008 in Ukraine. These and additional specimens examined by the author are marked with an asterisk (*). Analysis of general distribution of $V$. viburni is based on the data listed in the cited below bibliographic sources and databases available through the internet including GBIF Portal (http://data.gbif.org), USDA Fungal Database (http://nt.arsgrin.gov/fungaldatabases), Cybertruffle (www.cybertruffle.org.uk), etc.

Microscopic observations were made on dried material after mounting in distilled water or $1 \%$ cotton blue in lactophenol. Measurements were done based on 20 dimensions of asci, spores and conidia in each of the studied specimens. Photographs of general appearance were taken under Carl Zeiss STEMI 2000-C stereomicroscope. Microphotographs were taken under Primo Star microscope, Canon A300 digital camera and AxioVision 4.7 software, also used for measurements of microstructures.

The author's collections from Ukraine are deposited in Mycological Herbarium of the M.G. Kholodny Institute of Botany in Kiev, Ukraine (KW).

\section{RESULTS AND DISCUSSION}

Valsa viburni Fuckel

Jahrbücher des Nassauischen Vereins für Naturkunde 23-24: 201 (1869-1870) [1870].

(Fig. 1)

- Engizostoma viburni (Fuckel) Kuntze, Revisio Generum Plantarum 3 (2): 475 (1898)

Stromata scattered, subglobose to conical truncate, up to 2-2.5 mm diam. at the base, immersed in the bark and erumpent. Ectostromatic disc prominent, whitish grey or ashy to olive, circular to oval, up to $1 \mathrm{~mm}$ diam. Ectostroma inside light grey to brownish grey, surrounded from top to bottom by a thin blackish ventral zone gradually disappearing below. Entostroma indistinct; sometimes a very fine blackishgrey layer below ascomata is present. Ascomata perithecial, (3-) 8-12 (-19) in each stroma, arranged more or less in a circle, laterally inclined, black, globose or subglobose, with long ostiolar beaks thickened at the top. Ostioles usually centrally inserted, appearing on the disc as a loose cluster, often slightly projecting Asci 8-spored, clavate or subclavate, unitunicate, 54-68 $(-77) \times 8-10 \mu \mathrm{m}$, becoming detached at the base and freely floating, with inamyloid apical ring. Ascospores allantoid, aseptate, colourless, (9.5-) 11-13 (-16.5) × (1.8-) 2.5-3 (-4.2) um. Paraphyses not observed. 


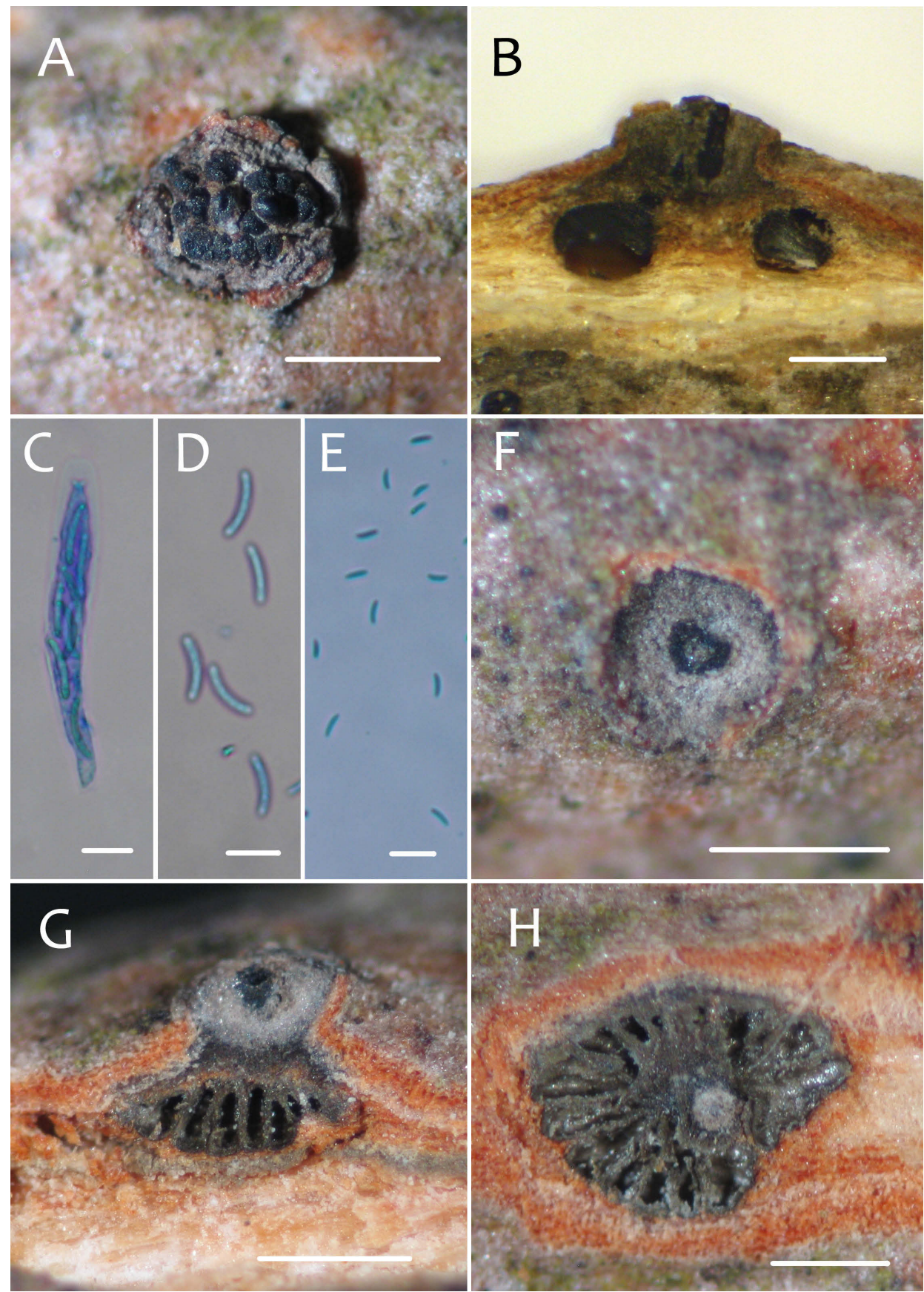

Fig. 1. Valsa viburni: A. Stroma in surface view showing perithecial bumps and ectostromatic disc with a bunch of projecting ostioles, B. Stroma in vertical section, C. Ascus, D. Ascospores, E. Conidia, F. Pycnidial stroma in surface view, with prominent ectostromatic disc and wide ostiole, G. Vertical section of pycnidial stroma showing a blackish zone underneath, H. Conidioma in transverse section. Scale bars for $A, F, G=500 \mu \mathrm{m}$, for $B=250 \mu \mathrm{m}$, for $C-E=10 \mu \mathrm{m}$, for $\mathrm{H}=300 \mu \mathrm{m}$. 
Pycnidial stromata quite similar in shape to those of teleomorph, up to $1.5 \mathrm{~mm}$ diam. Ectostromatal disc prominent, up to $500 \mu \mathrm{m}$ diam., more or less circular, whitish or light-grey to ashy, with one, rarely 2 ostioles; ostiolar canal widening towards the top, ostiole black, rounded to elliptical or sometimes compressed, projecting or at the same level as disc surface. Ectostroma greyish to dark grey inside, laterally surrounded by a thin blackened layer clearly visible in tangential sections through its upper part and gradually disappearing below. Entostroma not distinct; ventral blackish zone occasionally present. Conidiomata circular, elliptical or irregular, multi-chambered, comprising numerous radially arranged locules connected in the centre, each with additional invaginations. Conidiophores unbranched or branched, colourless, 9-15 $\times 2 \mu \mathrm{m}$. Conidiogenous cells cylindrical, slightly tapered at the apex, 6-8 $(-11) \times 1.5-2 \mu \mathrm{m}$, each with a minute collarette and a little periclinal thickening. Conidia allantoid to nearly straight, aseptate, colourless, (3.6-) 4-4.8 (-5.2) × 1-1.2 $\mu \mathrm{m}$.

On corticated twigs and small branches of Viburnum lantana $\mathrm{L}$.

GeographicAl distribution. EUROPE: Austria, Bulgaria, Czech Republic, Germany, Italy, Romania, Switzerland, Ukraine. NORTH AFRICA: Morocco.

This distribution is based on the following specimens or bibliographic references: AUSTRIA: V.1939 (Petrak, 1940). BULGARIA: 26.06.1989, V. Fakirova (Fakirova 2004; Stoykov, Denchev 2006; Stoykov 2012). CZECH REPUBLIC: 06.09.1957 (Urban 1958). GERMANY: 05.1893, J.N. Schnabl (Allescher \& Schnabl, Fungi Bavarici, no. 250), BR 099228, 94*; 04.1896, J.N. Schnabl (Rabenhorst-Pazschke, Fungi europaei et extraeuropaei, no. 4163), BR 099229,95*. ITALY: Northern Italy (Saccardo 1882). MOROCCO: 07.11.1960, R. Bertault, MPU B03403. ROMANIA: 27.07.1964 (Sandu-Ville 1971). SWITZERLAND: 02.05.1871, P. Morthier (Herbier Barbey-Boissier, no. 231), BR 099227,93*. UKRAINE: Vinnytsia Region, 15.07.1983; Cherkasy Region, 02.09.1984, V. Hayova (Merezhko, Smyk 1991); Khmelnytskyi Region, 25.08.2008; V. Hayova, KW 39968*, KW 39969*; 28.08.2008; V. Hayova, KW 39970*, KW 39971*.

V. viburni and its anamorph have several diagnostic features. Externally, they have prominent greyish discs with either a projecting cluster of ascomatal ostioles, or a single conidiomatal ostiole widened at the top (Fig. 1A, F, G). In addition, in both states ectostroma is encircled by a thin black line, often visible outside and particularly on transverse sections below ectostromatic discs, also noticeable on vertical sections (Fig. 1B, F, G). Another distinctive character, a blackish or dark grey ventral zone underneath stromata is often present (Fig. 1G). More detailed description of morphological characters of this species as well as notes on its subgeneric position, connection with anamorph etc. is published separately (Hayova, Minter 2012).

Quite close to $V$. viburni is one of the most common and widespread Valsa species, $V$. ambiens, occuring on numerous hosts including Viburnum (e.g. V. opulus). V. viburni differs from $V$. ambiens by smaller ascospores and asci, general appearance of ostioles, ectostromatic disc and structure of ectostroma. Due to scanty descriptions, these distinctions are usually not indicated resulting in misidentifications. For example, a report of $V$. viburni from Sweden (UPS BOT F-133236, on Viburnum opulus, K. Holm \& L. Holm, 28.10.1984) is presumably erroneous and refers to $V$. ambiens.

There are two other Valsa taxa described on V. lantana: Valsa perfodiens Nitschke and $V$. opulina Sacc. f. lantanae Bres. The former species has much smaller microstructures, asci $28 \times 4 \mu \mathrm{m}$ and spores $8 \times 2 \mu \mathrm{m}$ (Saccardo 1882); the latter form has similar dimensions of asci and spores to V. viburni (Saccardo 1891). 
In our observations, anamorph and teleomorph usually develop in separate stromata. They are scattered and intermixed on the same twig, or occur on different twigs. The anamorph occasionally can be observed on dying plant parts and the fungus probably becomes saprobic later, when ascomata are produced. The teleomorph can be found both on attached and fallen twigs. It is entirely possible that like many other Diaporthales members (Rossman et al. 2007), V. viburni may colonize healthy twigs and remain there as a symptomless endophyte.

Unlike many widespread valsaceous fungi, this species is apparently rare on European continent. It is known as a single record in most of the listed above countries. Records from three countries (Switzerland from where it was described, Italy and Germany) are dated by the 19th century (Fuckel 1870; Saccardo 1882). Other three specimens were collected around mid-20th century from Austria, Czech Republic and Romania (Petrak 1940; Urban 1958; Sandu-Ville 1971). One collection from the late 80s was reported from Bulgaria (Fakirova 2004; Stoykov, Denchev 2006; Stoykov 2012). And the most recently, in Ukraine where the species was specifically sought, only six records from four localities within quite restricted area in south-west of the country were generated.

There might be several reasons for a small number of records of this fungus. First, as a species of microfungi it can be overlooked. However, $V$. viburni has quite large immersed stromata, usually conspicuous as bumps in the bark with prominent ectostromatic discs erumpent in the centre. Second, this species can be underrecorded because of declining number of experts capable to observe and to identify it. Still, many other species of Valsa inhabiting various hosts are quite frequently reported. Finally, so far it was found to occur exclusively on Viburnum lantana. Since the fungus is host-specific, it can be omitted if no attention is paid to the host plant during mycological observations.

The host plant, Viburnum lantana, occurs in woodlands, more frequently on their edges, and in open sites, particularly on calcareous soils in central, southern and western Europe. V. lantana has not yet been assessed for the IUCN Red List (IUCN 2012) but, from conservation point of view, most likely it could not be a cause for concern unless habitat destruction takes place regionally. Apart from natural habitats, this shrub is also frequently planted as ornamentals in parks, gardens or hedges. However, in ornamental plantations diversity of corticolous ascomycetes can be rather low, mostly due to lack of dead twigs. In our observations, only one locality of V. viburni was in a neglected decorative plantation and three others were in natural habitats on the limestone hills.

If the host plant was recognized as endangered, the associated fungus could be also regarded as a subject for conservation. However, $V$. lantana as well as the appropriate habitats do not seem to be rare. Neverthless, $V$. viburni is known hitherto from a restricted number of records. Thus, before any conclusion is made on how rare $V$. viburni is in Europe, it is necessary to seek for any additional records of the fungus within this area. The highly host limited association, quite uncommon in the Valsaceae family, simplifies searching for more localities of $V$. viburni. In the meanwhile, $V$ viburni can be assessed as Data Deficient using IUCN Red List Categories and Criteria (IUCN 2001). And lastly, apart from teleomorph, it is important to take into account data on occurrence of the anamorph; for this purpose, distinctive morphological characters of both states are provided. 


\section{CONCLUSIONS}

This study demonstrates the major problem in evaluating conservation status of microfungi, i.e. uncertainty if the species is actually rare or simply rarely recorded. As the initial steps towards recognizing microfungi as conservation targets, fungal species confined to threatened hosts can be also recognized as rare. In case of $V$. viburni, a rarely recorded host-specific species is associated with rather common host plant; however, the fungus can be as well considered for conservation purpose if no more earlier records are found and no more successful observations on its occurrence in appropriate habitats are reported. Regarding pleomorphic ascomycetous fungi, records of both states should be included in the species occurrence data.

Acknowledgments. The author is grateful to an anonymous reviewer for useful comments and suggestions on this manuscript.

\section{REFERENCES}

Castlebury L.A., Rossman A.Y., Jaklitsch W.J., Vasilyeva L.N. 2002. A preliminary overview of the Diaporthales based on large subunit nuclear ribosomal DNA sequences. Mycologia 94:1017-1031.

Fakirova V.I. 2004. New records of Bulgarian ascomycetes. Mycologia Balcanica 1: 41-43.

Fuckel K.W.G.L. 1869-1870 (publ. 1870). Symbolae mycologicae. Beiträge zur Kenntniss der Rheinischen Pilze. Jahrbücher des Nassauischen Vereins für Naturkunde 23-24: 1-459.

IUCN 2001. IUCN Red List Categories and Criteria: Version 3.1. IUCN Species Survival Commission. IUCN, Gland, Switzerland and Cambridge, UK. ii +30 pp.

IUCN 2012. IUCN Red List of Threatened Species. Version 2012.2. www.iucnredlist.org. Downloaded on 21 December 2012.

Hayova V.P., Minter D.W. 2012. Valsa viburni. IMI Description Sheets of Fungi and Bacteria, Set 193, Sheet 1928.

Merezhko T.A., Smyk L.V. 1991. Flora of the Fungi of Ukraine. Diaporthales. Kiev: Naukova dumka, 216 pp. [In Russian].

Petrak F. 1940. Beiträge zur Kenntnis der Pilzflora der Umgebung von Lunz am See und des Dürrensteins in Niederdonau. Annales Mycologici 38 (2-4): 121-180.

Rossman A.Y., Farr D.F., Castlebury L.A. 2007. A review of the phylogeny and biology of the Diaporthales. Mycoscience 48: 135-144. http://dx.doi.org/10.1007/s10267-007-0347-7

Saccardo P.A. 1882. Sylloge Fungorum 1: i-xix, 1-768.

Saccardo P.A. 1891. Sylloge Fungorum 9: i, 1-1141, 1891.

Sandu-Ville C. 1971. Ciuperci Pyrenomycetes-Sphaeriales din România. Editura Academiei Republicii Socialiste România, 409 pp.

Spielman L.J. 1985. A monograph of Valsa on hardwoods in North America. Canadian Journal of Botany 63 (8): 1355-1378.

Stoykov D.Y. 2012. Diaporthales. (In:) C.M. Denchev (ed.). Гъбите в България. Volume 8. Institute of Biodiversity and Ecosystem Research, Bulgarian Academy of Sciences, Sofia. 319 pp.

Stoykov D.Y., Denchev C.M. 2006. Current knowledge of Diaporthales (Ascomycota) in Bulgaria. Mycologia Balcanica 3: 179-185.

Urban Z. 1958. Revise Československých zastupců rodů Valsa, Leucostoma a Valsella. Rozpravy Československě Akademie Věd. 68 (12): 1-100. 